\title{
Contemporary Art and Citizenship Education: The Possibilities of Cross-Curricular Links on the Level of Content
}

MetOdA KeMPERL ${ }^{1}$

$\propto$ Unlike the previous phenomenon of modern art, contemporary art strives to return to society and everyday life, while thematising the current issues that the individual faces here and now. One of its more frequent topics is that of sustainable development, and the accompanying issues of environment, values, relations to others, etc. All such topics are part of the concept of active citizenship, which is why understanding contemporary art calls for active citizenship. This particularly holds true for relational art, which demands active participation on the part of the viewer. This paper inquires into the possibilities of the connection of contemporary art and citizenship education in elementary schools. Contemporary pedagogic doctrine highly encourages cross-curricular teaching; therefore, I have focused my analysis on the curricula of the subjects of Art Education, and Citizenship and Patriotic Education and Ethics, determining that (from this perspective) their link is quite troublesome. The absence of contemporary art from the curriculum of Art Education has been criticised on many occasions, but the problem of its curriculum seems to be of a conceptual nature. Only by a more intense inter-institutional link between schools and contemporary art galleries and museums can the common goals of art education and citizenship education be realised. This paper will, therefore, strive to show potential cross curricular links in content on three examples of participatory practices (Proletarians of All Countries, Beggar Robot and EU/Others), while warning (from the pedagogic perspective) against the often neglected fact that contemporary art is experienced here and now.

Keywords: Contemporary art, Participatory art practices, Citizenship education, Art education, Cross-curricular links

1 Faculty of Education, University of Ljubljana, Slovenia metoda.kemperl@pef.uni-lj.si 


\section{Links between Citizenship and Art education}

The doctrine of contemporary pedagogy encourages cross-curricular teaching; consequently the most recent updates to the new 2011 curricula required even further emphasis on cross-curricular activities. Teachers and schools were required to link different subjects more closely; excursions and trips were also supposed to become more interdisciplinary and include crosscurricular fields (Karba, 2008). Key innovations of the elementary school curricula included cross-curricular teaching and cross-curricular topics. There have recently been many papers written on this issue in Slovenia with regard to citizenship education, most commonly seeing potential links with the subjects of History, Geography and Slovene Language (for instance Davies, 2003; Mihelj, 2003; Resnik Planinc, 2003; Slater, 2003; Justin, 2003; Kunaver, 2006; Kostrevc, 2006; Devjak, 2007).

The political philosopher and theoretician of citizenship Will Kymlicka asserts that citizen education should not constitute a separate part of the curriculum, but rather one of them main objectives and principles that shape the whole curriculum (Kymlicka, 1999). In Slovenia, it is most commonly realised within the subjects of Citizen and Patriotic Education, and Ethics (hereinafter: $\mathrm{CPE})$. Some authors point out that programme content should be focused on the specific phenomena of pupils' surroundings, and that an interdisciplinary approach should deepen the understanding of their relations to the world or connect different subjects into an active project in which the links with everyday situations would reveal themselves (Drake, 1998, p. 154; Štemberger, 2007, p. 96). Interdisciplinary discussions ought to enable pupils to express their ideas and interpretations more easily, and to offer diverse opinions and perspectives (Hickman \& Kiss, 2010). Knowledge conveyed in such a way is integrated and contextualised, thus stimulating the transfer of knowledge and skills from one field to another. Hickman and Kiss (2010) claim that teaching pupils to transmit knowledge and skills from one field to another would enable applicability as well as a more integral and in-depth understanding of contents and learning concepts. Through a study conducted in 2010, the authors detected positive links between the interdisciplinary approaches and the ability to transfer knowledge and skills. In a cross-curricular study, Rawding and Wall (1991) conducted an experiment with the cross-curricular teaching of religion and art. In interviews with the participating pupils, they established that some of them not only discovered links between art and faith, but also started integrating aspects of experiences and knowledge outside the frames of the subjects of instruction. That is to say that the pupils not only successfully linked the topics 
of abovementioned subjects, but also learned the general concept of interdisciplinary thinking, while transferring that knowledge to other subjects and fields.

Since instruction and education are today perceived as means of life training, art education has a particularly salient role in this process (Hickman, 2005).

Bearing the above said in mind, all updated syllabi for elementary school subjects also propose cross-curricular teaching. Most syllabi not only suggest subjects suitable for cross-curricular links, but also examples of content for cross-curricular teaching. Moreover, they list examples of content and skills for cross-curricular activities on both vertical and horizontal levels of connection.

Only two among these syllabi limit themselves merely to listing potential subjects for cross-curricular teaching: CPE and Art Education (hereinafter referred to as $\mathrm{AE}$ ). The first of these emphasises that culture and sustainable development education should represent the central elements of disciplinary and cross-curricular approaches to teaching, and that cross-curricular education acts as a key condition of implementing the approach as a whole (Učni načrt: program osnovna šola: državljanska in domovinska vzgoja ter etika, 2011, p. $20,21)$. In contrast, the syllabus for AE is rather reserved towards concretising cross-curricular teaching.

At first, that seems rather unusual, since art in itself is already interdisciplinary and therefore most appropriate for cross-curricular teaching, as shown by Germ with the example of Greek art (2008, p. 43, 44). Every in-depth interpretation of an artwork requires an interdisciplinary approach, providing its multilayered explanation. As stated by Tavčar »[...] in museums and galleries, we endeavour to make young visitors link the artworks seen with the knowledge acquired in school within the subjects such as: history, geography, art history, literature, music etc. The visits enable them to bind together these contents, guided by museum educators in their descent into an artwork and its layers of meaning.« (Tavčar, 2008, p. 78).

\section{Contemporary art as a socially engaged practice}

Art is a communicative phenomenon, helping people understand various aspects of the world, which would otherwise remain beyond their reach. It is a key and crucial human and social activity (Freedman, 2003). Art is a social practice, since artists use their work to express their relationship to themselves, to others and to the world they live in; for that reason, they must effectively understand the social structure in which they act (Bourriaud, 2007, p. 92). Art is thus in itself connected with the concept of citizenship and should therefore, being a source of knowledge, convictions and values about ourselves and the 
world, be a part of every citizen's education (Dobbs, 1998, p. 9). Art is close to the objectives of citizenship education in as much as the in-depth interpretation of the artwork, based on poststructuralist methods (Grierson, 2003, p. 102; Knight, 2010, p. 240, 241) necessarily includes critical thinking as well as forming of attitudes and values. Together with knowledge of history, geography and Slovene language, familiarity with European and Slovene art is of crucial importance for the formation and preservation of national identity, which in turn is a component of citizenship education. It is also intertwined with the concept of multiculturalism, which is in its own right one of the key points of departure in education, since the lack of familiarity with our own culture renders difficult the relationship with and understanding of others. The knowledge of art in various cultures helps pupils understand not only their artworks, but also their people (Dobbs, 1998, p. 11). Visiting museums, galleries and other public spaces that enable the experience of art, is a part of wider social engagement, which is also the goal of education for citizenship. In Slovenia, this is of even greater importance, since such institutions are funded by public money, which is also why engaged citizens should be interested in what sort of activity they are supporting.

Thus, becoming acquainted with museums should be seen as the compulsory part of the elementary school curriculum. In this way, according to Halstead and Pike (2006, p. 66), children, as future taxpayers, would be accustomed to consuming the very thing they fund, while developing a critical relationship to it. That is to say, if the citizens see no need for the production of artworks, the functioning of art institutions is financially at risk, according to the authors (Halstead \& Pike, 2006, p. 66). Generally speaking, museums shape common values with their exhibition policies, and since their activities are state funded, one would deduce that the state concerns itself with the values it propagates through the funding of museums as public institutions. ${ }^{2}$

Art has always been perceived also as a part and means of education: that is to say as part of a long-term altering of our behaviour and demeanour (Vigotski, 1975, p. 319). The aesthetic experience and the response to it can lead a child to re-evaluation and reflection of his/her relations, values, expectations and even confrontation with its prejudice, which makes it potentially morally educative (Halstead \& Pike, 2006, p. 64, 65). Due to its interdisciplinary nature, the suitable choice of an artwork (from whatever period it might originate)

2 This problem goes beyond the intent of this article and would probably be best replied to by philosophers or aesthetics scholars. We should here only warn that before the Enlightenment the two major supporters of art were the Church and the aristocracy (to a lesser extent also the bourgeoisie), who were well aware of what they were ordering or paying for (see also Žerovc, 2011c, p. 13, and Žerovc, 2012, pp. 10-12). 
makes it easily linked with all the contents and objectives of citizenship education. Hills-Potter has already shown that art can induce people into participation in society and impart a relationship required for active citizenship, especially an empathic one (quoted in Halstead \& Pike, 2006, p. 66).

Halstead and Pike found examples of art relevant for citizenship in the graffiti and the English painting of the 18th century, specifically in Hogarth's series Harlot's Progress, which is explicitly morally educative. They propose that the depiction of the story of a poor farm girl, who arrived to London in the beginning of the 18th century in search of a better life, becoming a prostitute and shortly after dying of syphilis, leaving behind a destitute child, serves to induce children into talks on sexual ethics, local authorities, current forms of prostitution, emmigration etc. Thus, they are supposed to realise the goals of citizenship education (Halstead \& Pike, 2006, pp. 71-74).

In the light of Vigotski's assertion that art presents the original and the most powerful weapon in the battle for survival, that it is the most critical intersection of all biological and social processes of a person in society, and that without new art there cannot be a new man, (Vigotski, 1975, pp. 312-327), let us examine what contemporary art is like, especially in terms of its links with the concept of active citizenship.

Contemporary art differs highly from its predecessor, modern art, which endeavoured to liberate itself from the ideological constraints; it wanted to not be illustrative. The artists considered themselves geniuses, creators, inventors; the only imperative they stuck to was the search of the new and the original. The modernists treated the painting as a two-dimensional surface, covered with paint, refusing to show anything besides that. For that reason, modern art became acutely detached from society.

In contrast, contemporary artists are not interested in progress or the new, nor in specific trends; they are allowed the plurality of ideas, materials and media. Heterogeneity is one of crucial aspects of contemporary art. The will to approach life, society and speaking about our everyday life through various artistic practices is what many contemporary artists have in common. The presentation of contemporary art is no longer bound to museums and galleries, but rather moves to other public spaces, such as shopping malls, which provides it with an audience that is not in touch with art and would never be seen in an art institution. Many artists, rather than being closed in their studios, work in their social surroundings or in partnership with the community or visitors. Thus, collective aesthetics enter the limelight. Artists do not see their practice as an elevated activity, but rather compare their profession with others. That is why contemporary art is no longer an autonomous field detached from life, as 
was the case with Modernism, but a field intertwined with the wider political, cultural and social context, while consciously responding to its position, as well as reflecting cultural and social issues of the present (Krauss, 1988; Groys, 2002, pp. 11-22; Weintraub, 2003; Millet, 2004, pp. 11-39; Zabel, 2000, pp. 261-264; Zabel, 2005, pp. 6-19). The artworks in which the audience actively participates, in which the audience is part of the art process, no longer revolve around the notion of the final product, but emphasise the idea that stays in participants' memory as well as the development of the artwork in their emotions. These sorts of works are finalised by explanations and actual involvement from the part of the audience (Millet, 2004, pp. 29-35). We speak of relational art (Bourriaud, 2007) or participatory practices, or of socially engaged artistic practices (Helguera, 2011), which appeared in the 1990s.

With their practices, contemporary artists strive to change people's perception of a certain problem. World famous performance artist Uwe Laysiepen has been intensively dealing with water in recent years. On the occasion of his participation on the project with the European Capital of Culture in Maribor, he wrote: »My wish is to give a different idea, different image of water. It is about making people think and changing their attitude to water, to feel more connected to it. (Pungerčič, 2012). Šejla Kamerić, who has exhibited her work in Slovenia several times, wrote about her internationally renowned work Bosnian Girl: "My goal was not to find the wretched fellow who wrote such rubbish on the wall, but to divert the attention to the responsibility of those who send utterly immature people to conflict-stricken areas to save lives « (Megla, 2012). Sašo Sedlaček warned about the sell-out of public frequency spectrum in his project Infocalypse now!, stating: »Just recently we carried out the action named Manifesto in the parliament in order to give the MPs a lesson in proper behaviour.« (Tratnik, 2009, p. 17). ${ }^{3}$

Due to its plurality, contemporary art offers diverse views, thus setting an example of tolerance, respect and critical thinking. Artists today act as researchers of life in the $21^{\text {st }}$ century, trying to react to various phenomena of our everyday existence. They focus on current social, political and economic issues, such as sustainable development, globalisation, migration or intercultural exchange, while others tackle more intimate questions of human relations, memory, life and death. All these issues concern the concept of citizenship. Many of today's social problems are omitted from the curricula and are also excluded from the mass media reporting. Using the example of discrimination, Mihelj showed (2003, p. 20) that although history textbooks for elementary schools

3 Sašo Sedlaček was in his function as an artist already involved in the teaching process (Kulturni bazar 2012: Program profesionalnega izobraževanja, 2012). 
mention it, they do so only in the context of fascist and Nazi »occupiers «, with no reference to it in the context of the present. Contemporary art, by contrast, offers suggestive reflexions on discrimination, as we shall show further ahead. Contemporary art responds to current issues before they become part of wider awareness. That is why contemporary art helps us understand our present, offering an insight into the social structure we live in and encouraging us to take part in its creation. Through these participatory practices, the artist forms specific kinds of communities, while the viewers become involved in the process, thus allowing the artwork to take place within them, in their emotions that arise with their participation. What occurs is, in fact, a personal experience, which enables us to reflect a certain phenomenon, behaviour, or event. It forces the participants to experience even the traumatic, which can later be reflected upon by ourselves or in communication with others. Contemporary participatory practices also offer a possibility to execute a potentially morally questionable action on a symbolic level, thus creating a platform for contemplation. In Kolding (2000) and in Dornbirn (2006), participants were to that end invited to liquidise a goldfish in a blender (Žerovc, 2011a, p. 108). Before taking on the act, they were asked to thoroughly consider it, bearing in mind our ambivalent relationship to animals. It is clear that participatory practices are educative in their very essence, being remarkably similar to the pedagogical method of roleplaying game and simulating concrete life experiences, both recommended for the process of teaching active citizenship (Židan, 2004, p. 51, 52; Učni načrt: program osnovna šola: državljanska in domovinska vzgoja ter etika, 2011, p. 20). It is necessary to emphasise that participation in contemporary art does not imply an acted simulation, but rather the authentic, true role play, which is much more convincing than merely observing an image. These practices are almost never individual, but emphatically collective, which is a fact that in itself encourages participants to exchange feelings and ideas after the event.

Since we still lack a methodology for evaluating contemporary art (Millet, 2004, p. 66), it is perhaps most convenient to help ourselves with poststructuralist methods in its understanding and pedagogic interpretation. These methods interweave various disciplines that also open the questions of ourselves (Larcher and Hooper-Greenhill, as quoted in Tavčar, 2001, p. 26). Such conversations enable the understanding not only of the artwork, but also ourselves and each other, while nurturing understanding towards the views and opinions of our peers, which is one of the objectives of citizenship education. While discussing contemporary art, the pupils simultaneously talk about the context in which it arose, the idea that it bears, and the reason it was created. In other words, about the world in which they live, thus widening their horizon, 
asking questions and discussing contemporary issues they themselves face. They recognise the problems of contemporary society, which (again) is one of the goals of education for citizenship.

Let us now take a closer look at these goals. CPE is a compulsory subject in the 7 th and 8th grades. I will try to analyse the objectives of this subject, establishing possible links with the contents dealt with in contemporary art.

\section{(Lack of) links between the Art education syllabus and the syllabus for Citizenship and Patriotic education, and Ethics}

The contents of contemporary artistic practices mentioned above can be associated with all of the general objectives of CPE (»the development of political literacy«, »of critical opinion and various opinions and values», »active inclusion of pupils in social life«). These objectives are developed through:

- discussions about the coexistence of different people and social groups, following of current social, political, economic and ecological issues,

- debates on the principles of ethics,

- recognising the violations of human or children's rights, etc. (Učni načrt: program osnovna šola: državljanska in domovinska vzgoja ter etika, 2011).

The contents of contemporary artistic practices are best linked to the following operative objectives for the $7^{\text {th }}$ grade:

- They should understand the importance of mutual tolerance for the benefit of the community;

- They should understand the origins of the notion of others and of the different. They should be able to recognise stereotypes and prejudice in the media and everyday life, while developing a critical stance towards them. They should understand the importance of tolerance and mutual respect for the culture of coexistence;

- They should develop the ability to express opinions.

The contents of contemporary art practice also coincide with all of the objectives listed in the unit "Slovenia was established on the basis of human rights «. Within the $8^{\text {th }}$ grade syllabus, contemporary art contents align with the unit »Finances, labour and economy«, as well as with all goals stated in the unit »World community«.

Contemporary art is omitted from the AE syllabus, since the syllabus is structured in terms of artistic modelling through which the pupils learn to 
express themselves. It consists of the modelling on a surface and the threedimensional modelling. It excludes contemporary art media as well as contemporary art per se, since the syllabus does not include artistic periods or styles. The exclusion of contemporary art and its media has been criticised for almost the previous fifteen years, first by Zupančič (previously Vrlič) (Vrlič, 1998; Vrlič, 2000; Vrlič, 2001; Vrlič \& Čagran, 2003; Zupančič, 2008; Duh \& Zupančič, 2009), but the real problem of the syllabus is its inadequate conceptual structure (Bračun Sova \& Kemperl, 2012). In the published studies and examples of successful practices, we find that Zupančič and Duh also showed their pupils the works of contemporary artists. Their approach seems rather inconsistent, since they included typically modernist works, such as those of Piet Mondrian (Duh \& Zupančič, 2009; Duh \& Herzog, 2012, p. 25). Moreover, they usually choose works by foreign artists (reproductions of artworks), which cannot be found in local museums and galleries. ${ }^{4}$ From Duh's comment that in choosing the artwork one ought to consider its quality (Duh, 2008, p. 103; Duh \& Zupančič, 2009; Duh \& Herzog, 2011, pp. 21-22), we are left to conclude the works by Slovene artists and those in Slovene galleries fail in complying with these standards of quality.

There is only one objective to be found among the general goals of the AE Syllabus that could be accomplished through introducing contemporary artistic practices, namely that »the pupils should develop sensibility towards cultural and artistic heritage, and cultural diversity«. In fact, this has nothing to do with contemporary art practices, which do not yet constitute a heritage. Furthermore, the operative goals for the third triad state:

- with the help of artworks, pupils' own works, and examples from nature and the environment, they become familiar with the concepts associated with modelling on a surface,

- they develop the ability to analyse and value the works of art,

- they become familiar with the artworks of national and international cultural heritage,

- $\quad$ with the help of artworks, pupils' own works, and examples from nature and the environment, they become acquainted with the concepts associated with $3 \mathrm{D}$ modelling,

- they become familiar with relevant artworks from different fields of art, which are part of national and world cultural heritage.

The third and the fifth of the listed goals cannot be associated with contemporary art, since it does not constitute heritage. The second and the fourth

4 With the exception of a study by Zupančič, published in 2001 (Vrlič, 2001). 
objective could be linked with contemporary art practices, but these goals only imply insights into art concepts such as composition, saturated colour, colour harmony, air perspective, horizon, spatial plan, architectural sculpture, masonry and framing in construction, and composition by adding elements. Contemporary art, however, places more emphasis on content, ideas or concepts than on form. Therefore, introducing contemporary art could be placed only within the second objective. It is interested that the objectives for the first triad state that during visits to art exhibitions pupils become open to diverse modes of artistic expression, while the objectives for the next two triads omit this.

Visits to galleries are next mentioned in the chapter dedicated to didactic recommendations. In the very beginning, it states: »In the frame of art education, the teachers constantly provide cultural education. They meaningfully include examples of artworks, in images or as originals, in particular stages of the teaching process. In order to attain an in-depth understanding of artworks, the teacher should take the pupils for a visit of a museum or a gallery exhibition, organise an artist talk or a studio visit, at least once a year « (author's translation).

Further on, the didactic recommendations are divided according to triads, but there are no instructions for the third triad for the visits or understanding artworks. What exactly is meant by understanding artworks is explained in the didactic recommendation for the first triad: »They integrate the artworks meaningfully and creatively in particular stages of the teaching process as an illustration (means of instruction) for familiarising artistic concepts, particularities of artistic techniques or motives « (author's translation). This once again shows the conceptual problem of the syllabus's basic scheme (Bračun Sova \& Kemperl, 2012). There is also no mention of understanding of artworks in the context of verification and assessment of knowledge, which might be due to the fact that in AE only pupils' works are supposed to be graded. We could nevertheless grade pupil's knowledge through his work, especially in terms of the standard of knowledge that states: "explain the importance of cultural heritage in Slovenia and the world «. We are left to wonder if this standard also included the understanding of art and why it seems to include all cultural heritage, and not only that of an artistic nature.

The analysis shows that we are entitled to wonder whether the pupils of the third triad in AE lessons actually come into contact with contemporary artistic practices, and if so, to ask ourselves in what way they deal with them. This is the point where we reach the issue of cross-curricular teaching.

The CPE Syllabus offers remarkably few recommendations for crosscurricular teaching, emphasising only the central position of cultural education 
and sustainable development education in the context of disciplinary and crosscurricular approaches to teaching. Neither does it concretise the contents and subjects with which the connection is possible. The definition of the subject lists as two among five key modes of achieving the goals of AE »the application of problem-based tasks to art and visual culture « and »the link with other groups of subjects as well as with everyday life." It recommends the intertwining on the level of artistic concepts: »1. Linking artistic concepts with the concepts from fields of other subjects, based on verbal, oral or written interpretation. 2. Linking artistic concepts with concepts from fields of other subjects, based on artistic interpretation - artistic expression. The proposed tasks are to be realised in an artistic way. " The statement is based on an professional article by Tacol (2002), suggesting the two approaches listed above. In the explanation of the second approach, Tacol states that the discussed artistic problem can be an artistic motif. She gives an example of a horse motif, asserting that the artistic exercise should nevertheless be liked with a certain artistic concept, such as a dot, a line, primary or mixed colours, etc. She adds that »interdisciplinary teaching merely in terms of extracting motifs out of contents of other subjects and their realisation through a certain art technique is unacceptable« (ibid., p. 46). In any case, cross-curricular teaching in the context of AE must be associated with an artistic concept, which is artistically theoretical and conceptually modernist, while also discernible in the pupil's work.

The analysis implies that the goals, such as developing the ability of analysing and assessing works of art, or understanding the artworks of national and international cultural heritage, are in fact not to be connected, since they are not foreseen in the proposed version of cross-curricular teaching.

It is perhaps for that reason that the daily activities in elementary schools only rarely include artistic activities, be it on the perceptive or productive level, as ascertained by Duh and Herzog (2012). This probably accounts for the fact that there are so few published ideas on how to link AE and citizenship; the existent few are associated with only one topic, conservation of environment, building on the issues of waste. In this context, the main proof of pupils' understanding of the issue are their works made of refuse (Zupančič, 2009; Duh \& Herzog, 2011; Duh \& Herzog, 2012). ${ }^{5}$ The use of litter as artistic material may point more to the support of ideology of recycling that to the true understanding of the problem. It is often the case that the companies that recycle waste are the same ones that consciously produce it in order to make a profit. Large American and European companies export their toxic waste to Africa causing deaths of local people as Greenpeace's studies have clearly shown (Omladič, 2011, p. 12).

5 At this point, one must caution against the inconsistencies in the choice of artists. 
Flajšman (2009) took up a more in-depth study on AE and environmental issues from the perspective of environmental protection, trying to strike a balance between communicativeness and art forms. During his research, he showed pupils ten works of art with environmental messages. It is intriguing that eight among them were posters or postcards with very clearly articulated messages, since this is one of the characteristics of a good poster. Only two were thus works of art, and were shown on images, both being works by American artists. It is also interesting that the author decided to carry out the study in the 9th grade, which meant that he could not connect it to the subject Citizenship and Ethics, in the framework of cross-curricular teaching. In this period, the environmental issues were dealt with by these subjects in the 8th grade (Učni načrt: program osnovna šola: državljanska vzgoja in etika, 1999, p. 32).

The compelling fact remains that none of the mentioned authors informed the pupils about the works of the Slovene artistic collective OHO, whose members were the first in Slovenia to start dealing with environmental issues. In the third phase of the group's existence, they were executing land art projects, which were much less invasive than those carried out by their American colleagues, and were intended to be erased by the passing of time (Kočevar, 2009, p. 150). Environmental issues were the main topic of Marko Pogačnik's subsequent solo career (Ravnikar, 2009, p. 32), as well as that of Marjetica Potrč, a world-renowned Slovene artist (Ravnikar, 2009, p. 32; Vovk, 2009, pp. 70-76). The previously mentioned Sašo Sedlaček, one of Slovenia’s most prominent contemporary artists, has been dealing with the conservation of environment, mostly with issues of waste and recycling, for the last ten years (Grafenauer, 2011). These artists hardly lack quality. Marko Pogačnik, for example, had an extensive retrospective in 2012 in the Museum of Modern Art in Ljubljana, entitled The Art of Life - The Life of Art. At the time this article is being written, Pogačnik is lecturing on the topic of healing the Earth with litopuncture at UNESCO headquarters in Paris (M. K., 2012). In 2011 Marjetica Potrč made Newsweek magazine's list as the third most influential contemporary artist in the world, emphasising her social engagement in the favelas of South America. ${ }^{6}$ Sašo Sedlaček was awarded several Slovene and international prizes, among others the OHO Award in 2006; in 2012, he was nominated for Henkel Art Award for Central and Eastern European Artists (T. C., 2012). In 2012, his solo exhibition was held at the Koroška Art Gallery in Slovenj Gradec, also shown in 2012 at the Jakopič Gallery in Ljubljana.

6 Marjetica Potrč participated at the Venice Biennial, The Sao Paolo Biennial, the Skulptur-

Projekte show in Münster, among others. In 2000 she was awarded the prestigious Hugo Boss International Award for Contemporary Art, which included a solo show in the Guggenheim Museum in New York (Gopnik, 2011). 


\section{Three examples: Proletarians of all countries, Beggar robot, EU/others}

To illustrate the possibility of connecting participatory practices with Citizen Education, let us take one of the general objectives of the CPE Syllabus: the perception of the stereotypic representations of the others and of the different. My choice of objective was influenced (among others) by the findings of researchers in the project Comparative Study of Citizen Education and Instruction - CEP (the research took place in 1999 and included pupils from 28 countries), which ascertains that Slovene pupils have a less positive relationship to immigrants, a fact that causes concern among social scientists and requires further analysis (Educational Research Institute, 2002 ${ }^{7}$ ).

Art itself has in the past generated prejudices. Thus, the relief on the tympanum of St. Madeleine's church in Vézelay from 1130 can serve as an incentive for a discussion on discrimination or relationship to the other. The scene depicts Christ instructing the Apostles to spread the Christian faith all over the world. The lintel of the portal shows people that had not yet accepted the faith, and are therefore shown as "half-men « - some have pig snouts, others elephant ears, or are depicted as pigmies. The scene serves as a way of establishing the image of the infidels in the period of the Crusades, in which the Church played a crucial part.

Many contemporary artists tackle the issue from an entirely different perspective, focusing on the means of changing stereotypical representations. To illustrate this point, I will introduce three artworks or art events that were presented in Ljubljana over the previous ten years. Contact with original artworks is of key importance for all those involved with the arts (Charman, Rose, \& Wilson, 2006; Talboys, 2010). This particularly holds true for participatory artistic practices, since in their case, the artwork takes place in us and is therefore impossible to experience via reproduction. I intend to illuminate only a segment of the otherwise multi-layered and multifaceted artworks that concern the objective mentioned above.

On the occasion of the 29th Biennial of Graphic Arts in 2011 in Ljubljana, dedicated to the Art Event, we had an opportunity to participate in the artwork of the New York and Istanbul-based Turkish artist Serkan Özkay. The installation entitled Proletarians of All Countries (Proletarier aller Länder) featured thousands of small red plastic foam figurines, representing workers, glued to the gallery floor, with their clenched fists raised (Žerovc, 2011b, pp. 142-143).

7 In another international comparative study, conducted ten years later (2009) Slovene pupils had ceased to negatively deviate from the international average in that respect (Šimenc, 2012, p. 96). 
The figurines were laid out so close to one another that the visitor could not help stepping over them on his way to the next gallery hall. The visitor thus deliberately walked over the working class or even jumped on them, since the foam figurines would immediately return to their original position. Nevertheless by the end of the show some workers "yielded « under the weight of their oppressors. The set up was so distressing for some visitors that they even chose not to pass to the next room, since the idea of stepping over the workers was too much for them to bear. Others walked over the figurines as delicately as possible; some, on the other hand, utterly enjoyed squashing them. The artist chose a decidedly humorous way to induce us to reflect the issues of the proletariat nowadays and their place in society.

The next artwork is Beggar Robot (Žicar) by Sašo Sedlaček, who in 2006 roamed Ljubljana's City Park shopping centre, as well as the streets of Tokyo and Taipei. A year later, Ljubljana's homeless made good use of it; in 2012, we finally had a chance to see it exhibited at Sedlaček's retrospective. Sašo Sedlaček, one of the most prominent contemporary Slovene artists, tackles garbage, recycling and interpersonal relationships in the globalised world as his main concerns. He not only warns about these issues, but also offers (artistic) solutions. Beggar Robot was awarded several prizes abroad, as well as the Slovene OHO Award (Tratnik, 2009; Grafenauer, 2011). The work is a robot made out of discarded computer technology. In 2006, it circled Ljubljana's shopping area, where begging is banned, asking for money in bad Slovene. The robot proved a prolific beggar, earning more than 1000 Slovene tolars an hour. The project clearly showed that rather than to a living being, we give money to a microchip, to a robot that entertains us through its technologised humanity. The beggar was especially popular with mothers with children, who usually avoid the homeless. The reactions in Taipei were similar. Beggar Robot soon attracted attention from passers-by, unlike the human beggar standing lonely next to him. After the arrival of a policeman, the human vagrant was forced to leave, while the robot was allowed to proceed (Grafenauer, 2011, pp. 30-33).

In the frame of the European contemporary Arts Biennial Manifesta, which in 2000 took place in Ljubljana with the title Borderline Syndrome, Šejla Kamerić realised the installation EU/Others. Sarajevo-born Kamerić gained international repute with a 2003 work showing her image, staring at the viewer, with a graffiti inscription over it. The graffiti was written by a Dutch UN soldier on a wall of Srebrenica army barracks; the work thus tried to warn against prejudices and the need to liberate ourselves from them. In Ljubljana, she had signs attached to city's main square, reading EU citizens and Others, which at the period were seen on all EU border crossings. Today, Others has been replaced 
by a more politically correct term Non-European Citizens. Kameric found the whole idea shocking as she as a Bosnian citizen was at the time able to travel only without a visa to a handful of countries. It made her reflect on the question of identity, about who the others are and what her place as the other was on a pan-European biennial of contemporary art in Ljubljana. In that period, Slovenes were also among those with the status of others (Kamerić, 2000).

These three examples alone confirm Vigotsky's thesis that the »new« art offers endless possibilities for a »new « man. Or to rephrase it in the context of present-day circumstances: contemporary art can show us the way forward, the way out of crisis (environmental, interpersonal, of values etc.) contemporary art need only be followed, understood and experienced.

\section{Conclusion}

If, in the future, the concept of active citizenship begins to become adapted to the globalised and multicultural world, if it starts dealing with economic, political and social inequality not only within states alone, but internationally, taking as one of its foundations universal human rights, in other words global citizenship education (Židan, 2007, p. 14; Demaine, 2010; Davies \& Evans Ried, 2010, p. 217), understanding and experiencing contemporary art will indeed prove essential. The analysis showed that through familiarity with the contents of contemporary art, we can realise the objectives of active citizenship. Contemporary art is unique in recognising and critiquing truly current issues that are excluded from media coverage. It identifies the issues as they appear and anticipates their consequences. Sedlaček's 2003 action Just do it!, in which he walled over the entrance to one of Ljubljana's shopping malls with bricks made of advertisement brochures, tackles both the problem of consumption and that of waste and recycling. It was carried out at the height of Slovenian consumption frenzy, while we were all enthusiastic about the abundance advertising materials overflowing our letter boxes (Grafenauer, 2011, pp. 24-26). Šejla Kamerić covered the walls of Sarajevo with her image of the Bosnian Girl long before the international community recognised the Srebrenica genocide (Megla, 2012, p. 24).

Integrating contemporary art into the syllabus as it is conceived now seems problematic, since the experience of contemporary art, if it is to have the intended effect, is one of the present moment. Introducing contemporary art to the current syllabus would inevitably lead, due to unavoidable time lapse, to the loss of its contemporaneity. What is needed is a different concept of syllabus, as stated earlier (Bračun Sova \& Kemperl, 2012). 
It is extremely important to enable as much authentic contact with contemporary art as possible, simultaneously using up-to-date methods for experiencing and understanding art. Compared to earlier art, contemporary art is more difficult to teach in the classroom, since one can hardly reproduce an artistic event that requires one's participation. For that reason, a greater emphasis in the syllabus should be put on visits to museums, galleries and other spaces where contemporary art is presented, or artistic events take place. It is here that the pupils could be taught active citizenship in an authentic way, which would also prove beneficial for both $\mathrm{AE}$ and $\mathrm{CPE}$. That, however, requires a change of the concept of cross-curricular teaching of AE.

The foundation for a more frequent direct contact with contemporary art is found in the White Book on education, which explicitly defines the principles of cooperation between the school and its surroundings (Bela knjiga, 2011, pp. 114-117). A question arises from the point of view of inter-institutional cooperation about the qualifications of art teachers and museum educators. One would expect more commitment from the part of contemporary art institutions in attracting school groups, preparing materials on artwork and artists and introducing new interdisciplinary methods of work to teachers. Apart from the artist, it is the curator who is most familiar with the current art production. Most contemporary artists are not yet sufficiently known, which means teachers find it difficult to obtain adequate materials and sources. Slovene curators are unfortunately insufficiently aware of that role.

The responsibility of an elementary school should include offering pupils the tools needed to assess and engage with the scale of visual images never before encountered (Knight, 2010, p. 238). That is why we must decide whether we want our children to be raised by mass culture products of Hollywood provenance, which still promote the ideology of white male supremacy (as in the 2010 family film Marmaduke as well as other Disney products, analysed by Dorfman and Mattelart (2007)), or would rather discuss current social issues assisted by contemporary art in its attempt to change stereotypical images of the others and of us. In that respect, as was the case with the English education system a decade ago (quoted in Halstead \& Pike, 2006), the potential of art in Slovenia remains utterly unutilised.

I would like to thank Rajka Bračun Sova and Asta Vrečko for their remarks and kind assistance with writing this article. 


\section{References}

Bela knjiga o vzgoji in izobraževanju v Republiki Sloveniji (2011). Ljubljana: Zavod RS za šolstvo. Bourriaud, N. (2007). Relacijska estetika. Postprodukcija: kultura kot scenarij: kako umetnost reprogramira sodobni svet. Ljubljana: Maska.

Bračun Sova, R., \& Kemperl, M. (2012). The Curricular Reform of Art Education in Primary School in Slovenia in Terms of Certain Components of the European Competence of Cultural Awareness and Expression. CEPS Journal, 2(2), pp. 71-90.

Charman, H., \& Ross, M. (2002). Contemporary Art and the Role of Interpretation. Tate Papers, Autumn 2004. Retrieved Oct 15 2012, from http://www.tate.org.uk/research/tateresearch/ tatepapers/o4autumn/charman.htm

Charman, H., Rose, K., \& Wilson, G. (Eds.) (2006). The Art Gallery Handbook: A Resource for Teachers. London: Tate Publishing.

Davies, I. (2003). Državljanska vzgoja in poučevanje in učenje zgodovine. In J. Justin \& M. Sardoč (Eds.), Državljanska vzgoja pri pouku zgodovine, geografije in slovenščine (pp. 45-62). Ljubljana: i2. Davies, I., Evans, M., \& Reid, A. (2010). Globalizacija državljanske vzgoje? In J. Pikalo (Ed.), Državljanstvo in globalizacija: $k$ državljanski vzgoji za sodobni svet (pp. 207-238). Ljubljana: Sophia. Demaine, J. (2010). Globalizacija in državljanska vzgoja. In J. Pikalo (Ed.), Državljanstvo in globalizacija: $k$ državljanski vzgoji za sodobni svet (pp. 147-164). Ljubljana: Sophia.

Devjak, T. (2007). Nadgraditev ciljev predmeta državljanska vzgoja in etika v določenih orientacijah medpredmetnega in praktičnega življenja v šoli. In J. Krek (Ed.), Učitelj v vlogi raziskovalca: akcijsko raziskovanje na področjih medpredmetnega povezovanja in vzgojne zasnove v javni šoli (pp. 150-178). Ljubljana: Pedagoška fakulteta.

Dobbs, S. M. (1998). Learning in and through Art: A Guide to Discipline-Based Art Education. Los Angeles: The Getty Education Institute for the Arts.

Dorfman, A., \& Mattelart, A. (2007). Kako brati Jaka Racmana. Imperialistična ideologija v Disneyjevih stripih. Ljubljana: Maska.

Drake, S. M. (1998). Creating Integrated Curriculum. California: Corwin Press.

Duh, M. (2008). Likovna vzgoja v funkciji razvijanja ekološke zavesti otrok in mladostnikov. In M. Duh (Ed.), Razvojno-raziskovalni koncepti ekologije od vrtca do fakultete in naprej v prakso (pp. 95-114). Maribor: Pedagoška fakulteta; Rakičan: RIS Dvorec.

Duh, M., \& Zupančič, T. (2009). Sodobna likovna umetnost v kurikulu vrtca. Ljubljana: Zavod Republike Slovenije za šolstvo.

Duh, M., \& Herzog, J. (2011). Ekoart in likovnopedagoška praksa. In M. Duh (Ed.), Raziskovalni vidiki ekologije v kontekstu edukacije (pp. 17-32). Maribor: Pedagoška fakulteta Maribor, RIS dvorec Rakičan.

Duh, M., \& Herzog, J. (2012). Likovno-ekološki dan. In M. Duh (Ed.), Ekološka in etična zavest skozi edukacijski odnos do družbe in narave (pp. 14-29). Maribor: Pedagoška fakulteta Maribor, RIS dvorec Rakičan. 
Educational Research Institute (2002). Primerjalna raziskava državljanskega izobraževanja in vzgoje cep. Retrieved Oct 15 2012, from: http://www.pei.si/Sifranti/ResearchProject.aspx?id=16

Erjavec, A. (1996). K podobi. Ljubljana: Zveza kulturnih organizacij Slovenije.

Flajšman, B. (2009). Likovna dejavnost in ekološko osveščanje. Ljubljana: Debora.

Freedman, K. (2003). Teaching Visual Culture: Curriculum, Aesthetics and the Social Life of Art. New

York: Teachers College Press; Reston: National Art Education Association.

Germ, T. (2008). Koordinatorji kulturne ali koordinatorji umetnostne vzgoje? In N. Požar Matijašič

\& N. Bucik (Eds.), Kultura in umetnost v izobraževanju - popotnica 21. Stoletja (pp. 39-46). Ljubljana: Pedagoški inštitut.

Gopnik, B. (2011). The 10 Most Important Artists of Today. Art Beast, 5. Junij. Retrieved Oct 15 2012, from: http://www.thedailybeast.com/newsweek/2011/06/05/the-10-most-important-artists-of-today. item-3.html

Grafenauer, P. (2011). Velika prostovoljna čistilna akcija: Sašo Sedlaček! In S. Sedlaček, Supertrash (pp. 22-46). Ljubljana: Aksioma; Slovenj Gradec: Koroška galerija likovnih umetnosti.

Grierson, E. (2003). Framing the arts in education: what is really at stake? In E. Grierson et al. (Eds.), The Arts in Education: critical perspectives from Aotearoa New Zealand (pp. 93-118). Palmerston North: Dunmore Press.

Groys, B. (2002). Teorija sodobne umetnosti: Izbrani eseji. Ljubljana: Študentska založba.

Halstead, J. M., \& Pike, M. A. (2006). Citizenship and Moral Education: Values in action. London: Routledge.

Helguera, P. (2011). Education for socially engaged art: a materials and techniques handbook. New York: Jorge Pinto Books.

Hickman, R. (2005). Introduction. In R. Hickman (Ed.), Critical Studies in Art and Design Education (pp. 15-18). Bristol in Portland: Intellect.

Hickman, R., \& Kiss, L. (2010). Cross-Curricular Gallery Learning: A Phenomenological Case Study. International Journal of Art \& Design Education, 29(1), 27-36.

Justin, J. (2003). Didaktično besedilo, pretekli dogodki, današnji državljani. In J. Justin, \& M. Sardoč (Eds.), Državljanska vzgoja pri pouku zgodovine, geografije in slovenščine (pp. 123-138). Ljubljana: i2. Kamerić, Š. (2000). From the e-mail to Kathrin Rhomberg, curator for European Biennial of Contemporary Art - Manifesta 3. Retrieved Oct 15 2012, from: http://www.sejlakameric.com/art/ eu_others_text.htm

Karba, P. (2008). Opolnomočenje učencev za življenje etično aktivnih državljanov. Vzgoja in izobraževanje: revija za teoretična in praktična vprašanja vzgojno izobraževalnega dela, 39(6), 6-7. Knight, L. (2010). Why a Child Needs a Critical Eye, and Why the Classroom is Central in Developing It. The International Journal of Art \& Design Education, 29(3), 236-243.

Kočevar, M. (2009). Landart. In N. Zgonik (Ed.), Pojmovnik slovenske umetnosti po letu 1945: pojmi, gibanja, skupine, težnje (pp. 148-152). Ljubljana: Študentska založba, Inštitut ALUO.

Kostrevc, R. (2006). Državljanska in domovinska vzgoja - občutljiva in pomembna. In A. Barle Lakota \& E. Rustja (Eds.), Državljanska in domovinska vzgoja (pp. 146-153). Slovenska Bistrica: Beja. 
Krauss, R. (1988). The Originality of the Avant-Garde and Other Modernist Myths, Cambridge. London: MIT Press.

Kulturni bazar 2012: Program strokovnega usposabljanja (2012). Ljubljana: Ministrstvo za kulturo, Ministrstvo za šolstvo in šport, Ministrstvo za okolje in prostor, Zavod RS za šolstvo. Retrieved Oct 15 2012, from: http://www.arhiv.mk.gov.si/si/splosno/vstopna_stran/dogodki/kulturna_vzgoja_in_ kulturni_bazar/

Kunaver, V. (2006). Predmeta državljanska vzgoja in etika ter državljanska kultura v osnovni in srednji šoli ter njuna povezanost s predmetom zgodovina. In A. Barle Lakota \& E. Rustja (Eds.), Državljanska in domovinska vzgoja (pp. 142-145). Slovenska Bistrica: Beja.

Kymlicka, W. (1999). Education for Citizenship. The School Field: International Journal of Theory and research in education, 10(1-2), 9-36.

M. K. (2012). Marko Pogačnik v Parizu o Zemlji in našem odnosu do nje. Retrieved Oct 26 2012, from: http://www.rtvslo.si/kultura/drugo/marko-pogacnik-v-parizu-o-zemlji-in-nasem-odnosu-donje/294365

Megla, M. (2012). Šejla Kamerić, vizualna umetnica: Umetnost ni samo za privilegirane. Delo, Sobotna priloga, May 5 2012, 24-25.

Mihelj, S. (2003). Povezave učnega načrta državljanske vzgoje in etike z učnimi načrti slovenščine, zgodovine in geografije. In J. Justin \& M. Sardoč (Eds.), Državljanska vzgoja pri pouku zgodovine, geografije in slovenščine (pp. 19-23). Ljubljana: i2.

Millet, C. (2004). Suvremena umjetnost. Zagreb: Muzej suvremene umjetnosti.

Omladič, L. (2011). Piknik na smetišču. In S. Sedlaček, Supertrash (pp. 6-20). Ljubljana: Aksioma; Slovenj Gradec: Koroška galerija likovnih umetnosti.

Pungerčič, B. (2012). Ulay - Uwe Laysipen: Deliti z drugimi in skrbeti tudi zanje, ne samo zase. Retrieved Oct 15 2012, from: http://www.zivljenjenadotik.si/info/tekst/prikaz/article/ulay-uvelaysipen-deliti-z-drugimi-in-skrbeti-tudi-zanje-ne-samo-zase/

Ravnikar, B. (2009). Ekologija in umetnost. In N. Zgonik (Ed.), Pojmovnik slovenske umetnosti po letu 1945: pojmi, gibanja, skupine, težnje (pp. 28-32). Ljubljana: študentska založba, inštitut ALUO. Rawding, M., \& Wall, B. (1991). Art and religion in the classroom: a report on a cross-curricular experiment. International Journal of Art \& Design Education, 10(3), 293-306.

Resnik Planinc, T. (2003). Državljanska vzgoja in etika z vidika geografije. In J. Justin \& M. Sardoč (Eds.), Državljanska vzgoja pri pouku zgodovine, geografije in slovenščine (pp. 79-86). Ljubljana: i2. Slater, F. (2003). Vrednote in vzgoja o vrednotah v učnem načrtu geografije v odnosu do koncepta državljanstva. In J. Justin \& M. Sardoč (Eds.), Državljanska vzgoja pri pouku zgodovine, geografije in slovenščine (pp. 87-108). Ljubljana: i2.

Stibbs, A. (1998). Language in art and art in language. Journal of Art and Design Education, 17(2), 201-209.

Šimenc, M. (Ed.) (2012). Razvoj državljanske vzgoje v republiki Sloveniji: Konceptualni okvir in razvoj kurikulumov. Ljubljana: Pedagoški inštitut. Retrieved Feb 5 2013, from: http://www.pei. si/UserFilesUpload/file/digitalna_knjiznica/Dissertationes_22_ISBN_978-961-270-147-5_SWF/ 
ISBN_978-961-270-147-5.html

Štemberger, V. (2007). Načrtovanje in izvajanje medpredmetnih povezav. In J. Krek et al. (Eds.),

Učitelj v vlogi raziskovalca: akcijsko raziskovanje na področjih medpredmetnega povezovanja in vzgojne zasnove v javni šoli (pp. 93-111). Ljubljana: Pedagoška fakulteta.

T. C. (2012). Sašo Sedlaček med finalisti za Henklovo nagrado. Delo, 3.7.2012. Retrieved Oct 15 2012,

from: http://www.delo.si/kultura/dediscina/saso-sedlacek-med-finalisti-za-henklovo-nagrado.html

Tacol, T. (2002). Problemski pouk likovne vzgoje in medpredmetno povezovanje v novem

kurikulumu. Sodobna pedagogika, (2), 40-49.

Talboys, G. K. (2010). Using museums as an educational resource: An Introductory Handbook for Students and Teachers. Farnham in Burlington, VT: Ashgate.

Tavčar, L. (2001). Otroci, mladostniki in odrasli v galeriji. Priročnik za kustose pedagoge, učitelje, vzgojitelje in starše. Ljubljana: Narodna galerija.

Tavčar, L. (2009). Homo spectator. Uvod v muzejsko pedagogiko. Ljubljana: Pedagoški inštitut.

Retrieved Jan 11 2013, from: http://www.pei.si/UserFilesUpload/file/digitalna_knjiznica/

Dissertationes_3/index.html

Tratnik, P. (2009). Brkljanje, ki sproti rešuje probleme. Maska: Časopis za scenske umetnosti, XXIV,

119-120.

Učni načrt: program osnovna šola: državljanska vzgoja in etika (1999). Ljubljana: Ministrstvo za šolstvo in šport, Zavod RS za šolstvo.

Učni načrt: program osnovna šola: likovna vzgoja (2011). Ljubljana: Ministrstvo za šolstvo in šport,

Zavod RS za šolstvo.

Učni načrt: program osnovna šola: državljanska in domovinska vzgoja ter etika (2011). Ljubljana:

Ministrstvo za šolstvo in šport, Zavod RS za šolstvo.

Vigotski, L. S. (1975). Psihologija umetnosti. Beograd: Nolit.

Vovk, M. (2009). Utopične vizije, paralelne strategije, privilegirane taktike: trije primeri angažiranih praks v sodobni slovenski umetnosti - Tadej Pogačar, Marjetica Potrč, Franc Purg \& Sara Heitlinger. In T. Vignjević (Ed.), Interpretacije vizualnosti: Študije o sodobni slovenski likovni umetnosti (pp. 61-83). Koper: Založba Annales.

Vrlič, T. (1998). Sodobna likovna umetnost pri likovni vzgoji. Likovna vzgoja, (7-8), 21-24.

Vrlič, T. (200o). Smeri razvoja sodobnega predmeta likovna vzgoja. Likovna vzgoja, (11-12), 11-19.

Vrlič, T. (2001). Sodobna umetnost in likovnovzgojna praksa. Likovna vzgoja, (16-17), 16-23.

Vrlič, T., \& Čagran, B. (2003). Empirično uvajanje sodobnih vsebin v likovno vzgojo v osnovni šoli.

Sodobna pedagogika, (4), 126-142.

Weintraub, L. (2003). Making contemporary art: How today's artists think and work. London: Thames \& Hudson.

Zabel, I. (200o). Manifesta 3: Poročilo. Zbornik za umetnostno zgodovino, n. v. (36), 261-294.

Zabel, I. (2005). »Sodobna umetnost«. In I. Španjol \& I. Zabel (Eds.), 95-05. Teritoriji, identitete, mreže: Slovenska umetnost 1995 - 2005 (pp. 6-19). Ljubljana: Moderna galerija 2005.

Zupančič, T. (2008). Likovni kurikul - primerjava konceptov v luči prenove učnega načrta za likovno 
vzgoj. Revija za elementarno izobraževanje, 1(3-4), 33-44.

Zupančič, T. (2009). Ekologija kot primarni cilj likovne vzgoje? Primerjava osnovnih usmeritev finskega in slovenskega likovnega kurikuluma. In M. Duh (Ed.), Edukacija za trajnostni razvoj (pp. 81-96). Maribor: Pedagoška fakulteta Maribor, RIS dvorec Rakičan.

Žerovc, B. (2011a). Marko Evaristti. In P. Kisin \& B. Žerovc (Eds.), Dogodek. The Event, 29. Grafični bienale. The 29th Biennale of Graphic Arts. 23. September-20.november 2011. 23 September-20 November 2011 (p. 108). Ljubljana: Mednarodni grafični center.

Žerovc, B. (2011b). Serkan Özkaya. In P. Kisin \& B. Žerovc (Eds.), Dogodek. The Event, 29. Grafični bienale. The 29th Biennale of Graphic Arts. 23. September-20.november 2011. 23 September-20 November 2011 (pp. 142-143). Ljubljana: Mednarodni grafični center.

Žerovc, B. (2011c). O umetniškem dogodku na umetnostnem dogodku. In P. Kisin \& B. Žerovc (Eds.), Dogodek. The Event, 29. Grafični bienale. The 29th Biennale of Graphic Arts. 23. September-2o. november 2011. 23 September-2o November 2011 (pp. 13-21). Ljubljana: Mednarodni grafični center. Žerovc, B. (2012). Zakaj na likovnem področju razmišljati o umetniških dogodkih? Maska: Časopis za scenske umetnosti, 27(147-148), 10-15.

Židan, A. (2004). Za kakovostnejša družboslovna znanja: didaktični in znanstveni prispevki. Ljubljana: Fakulteta za družbene vede.

Židan, A. (2007). Vzgoja za evropsko demokracijo. Ljubljana: Fakulteta za družbene vede.

\section{Biographical note}

Metoda Kemperl, PhD in art-science, Assoc. Prof. of art history, works at the University of Ljubljana, Faculty of Education, Department of Fine Arts Education. Member of research program History of Art in Slovenia, Central Europe and the Adriatic. Co-founder of the Slovenian Society for the Study of 18 th century. Winner of awards Izidor Cankar for special achievements in art history, presented by the Slovene Art history society. Co-author and coordinator of the new master level study programme Museum Education. The main areas of research: Baroque Art, Baroque Architecture, Baroque cultural history, pilgrims Churches, museum pedagogy. 